\title{
Basolateral Localization and Export Activity of the Human Multidrug Resistance-associated Protein in Polarized Pig Kidney Cells
}

\author{
Raymond Evers, ${ }^{\star}$ Guido J.R. Zaman, ${ }^{*}$ Liesbeth van Deemter, ${ }^{*}$ Hans Jansen, ${ }^{\ddagger}$ Jero Calafat, ${ }^{\ddagger}$ Lauran C.J.M. Oomen, ${ }^{\S}$ \\ Ronald P.J. Oude Elferink, "Piet Borst, ${ }^{*}$ and Alfred H. Schinkel* \\ *Division of Molecular Biology, ${ }^{\ddagger}$ Division of Cell Biology, and ${ }^{\S}$ Division of Biophysics, The Netherlands Cancer Institute; ${ }^{\|}$E.C. Slater \\ Institute for Biochemical Research, University of Amsterdam, 1066 CX Amsterdam, The Netherlands; and "IDepartment of \\ Gastroenterology, Academic Medical Center, 1105 AZ Amsterdam, The Netherlands
}

\begin{abstract}
The human multidrug resistance-associated protein MRP confers resistance to various cytotoxic drugs by lowering the intracellular drug concentration. Recent evidence indicates that MRP can also transport glutathione $S$-conjugates across membranes. To study the transport properties of MRP in intact cells, we have expressed human MRP cDNA in the polarized pig kidney epithelial cell line LLC-PK1. MRP mainly localized to the basolateral plasma membrane of these cells, and not to the apical membrane, as determined by immunocytochemistry using confocal laser scanning and electron microscopy. In accordance with this localization, MRP caused increased transport of the glutathione $S$-conjugate $S$-(2, 4-dinitrophenyl)-glutathione and of the anticancer drug daunorubicin to the basal side of the epithelial cell layer. Sulfinpyrazone and probenecid, known inhibitors of multispecific organic anion transport, inhibited this basolateral transport, but not the apical transport of daunorubicin mediated by the apically localized human MDR1 P-glycoprotein in MDR1-transfected LLC-PK1 cells. Probenecid and sulfinpyrazone may therefore be useful lead compounds for the development of clinical reversal agents specific for MRP-mediated drug resistance. (J. Clin. Invest. 1996. 97:1211-1218.) Key words: multidrug resistance • reversal agents $\bullet$ glutathione $S$-conjugate $\bullet \mathrm{GS}-\mathrm{X}$ pump $\bullet$ sorting
\end{abstract}

\section{Introduction}

Upon exposure to a single cytotoxic drug, mammalian tumor cells can develop resistance against a range of drugs with different chemical structures and cellular targets (1). This phenomenon is called multidrug resistance (MDR) ${ }^{1}$. Thus far, two proteins have been identified that can confer MDR: P-glyco-

Address correspondence to Alfred H. Schinkel, Division of Molecular Biology, The Netherlands Cancer Institute, Plesmanlaan 121, 1066 CX Amsterdam, The Netherlands. 31-20-5122087; FAX: 31-206691383.

Received for publication 11 October 1995 and accepted in revised form 8 December 1995.

1. Abbreviations used in this paper: $\mathrm{CDNB}, 1$-chloro-2,4 dinitrobenzene; GS-DNP, dinitrophenyl-glutathione; GSH, glutathione; GST, GSH-S-transferase; MDR, multidrug resistance; MRP, MDR-associated protein; Pgp, P-glycoprotein.

J. Clin. Invest.

(C) The American Society for Clinical Investigation, Inc.

0021-9738/96/03/1211/08 \$2.00

Volume 97, Number 5, March 1996, 1211-1218 protein $(\mathrm{Pgp})$, and the multidrug resistance-associated protein (MRP; 2). Both are members of the ATP-binding cassette family of transporter proteins, and both confer resistance by decreasing the intracellular concentration of cytotoxic drugs $(1,3,4)$. Pgp is a $140-170 \mathrm{kD}$ plasma membrane protein that actively extrudes a range of relatively hydrophobic, amphiphilic, drugs from the cell. MRP is a $190-\mathrm{kD}$ membrane protein, which is also mainly present in the plasma membrane of resistant cells (4-6).

Recent studies suggest that the exact mechanism by which MRP and Pgp remove drugs from the cell may be fundamentally different. Inside-out plasma membrane vesicles isolated from $M R P$-overexpressing cells showed an increased ATPdependent glutathione $S$-conjugate uptake activity $(7,8)$. The experiments indicated that MRP is able to transport substrates that are conjugated to glutathione (GSH). Carriers with this property are known as GS-X pumps (9), multispecific anion transporters $(10)$, or the leukotriene $\mathrm{C}_{4}$ transporter $(7,11)$, and they have a relatively broad substrate specificity. They can transport substrates containing a hydrophobic and a negatively charged part $(9,10)$. In vitro evidence supporting that MRP mediates the transport of GS-X pump substrates was obtained by showing that leukotriene $\mathrm{C}_{4}$ can be cross-linked to a 190$\mathrm{kD}$ protein that is recognized by an antiserum against MRP (7). Evidence that the presence of GSH is a prerequisite for MRP-mediated MDR in intact cells was obtained by depleting cells of GSH by treatment with L-buthionine sulfoximine, an inhibitor of GSH synthesis. L-buthionine sulfoximine treatment resulted in the loss of resistance to doxorubicine, daunorubicine, vincristine and VP16 (12-14).

$M R P$ expression is found in all major organs analyzed and in all cell types from peripheral blood $(15,16)$, but its exact physiological function is not yet known. Pgp is found in the brush border of proximal tubules of the kidney, in the bile canalicular membrane of hepatocytes, in the apical membrane of mucosal cells in the intestine, and in the luminal membrane of endothelial cells at blood-tissue barrier sites $(17,18)$. The distribution of Pgp indicates that it can protect the organism against toxic xenobiotic compounds, which was confirmed by disrupting a Pgp gene in mice (19). For MRP several potential physiological functions can be envisaged, including a role in inflammation due to its capacity to transport leukotriene $C_{4}(9)$, and, in analogy with Pgp, a more general role in detoxification of cells by the export of GSH and other conjugates of potentially noxious compounds.

To study the transport characteristics of MRP in polarized cells, we have transfected $M R P$ cDNA into the epithelial pig kidney cell line LLC-PK1. Transfection of the MDR1 P-glycoprotein cDNA in this type of cells has yielded useful information regarding transport properties of this protein, which is predominantly found in the apical plasma membrane of these 
cells $(20,21)$. In contrast, we describe here that MRP is present in the basolateral plasma membrane, where it exports a GSHconjugate and $\left[{ }^{3} \mathrm{H}\right]$ daunorubicine to the basal side. This transport could be inhibited by classical modulators of the GS-X pump, such as probenecid and sulfinpyrazone.

\section{Methods}

Materials. $\left[{ }^{3} \mathrm{H}\right]$ Daunorubicin $(4 \mathrm{Ci} / \mathrm{mmol})$, inulin- $\left[{ }^{14} \mathrm{C}\right]$ carboxylic acid $(5.95 \mathrm{Ci} / \mathrm{mol}, \mathrm{mol} \mathrm{wt} \sim 5,200[\mathrm{~g} / \mathrm{mol}])$, and $\left[{ }^{14} \mathrm{C}\right]-1$-chloro2,4-dinitrobenzene $\left[{ }^{14} \mathrm{C}\right] \mathrm{CDNB}(10 \mathrm{mCi} / \mathrm{mmol})$ were obtained from Amersham International, Little Chalfont, U.K. Other chemicals and drugs were from Sigma Chemical Co., St. Louis, MO.

Cell lines. LLC-PK1 pig kidney epithelial cells were obtained from the American Type Culture Collection and cultured as described (21). LLC-MRP was obtained by transfection of LLC-PK1 cells with the expression vector $\mathrm{pRC/RSV-MRP,} \mathrm{containing} \mathrm{a} \mathrm{human}$ $M R P$ cDNA (4). The calcium phosphate coprecipitation technique was used $(22,23)$. Transfected populations were selected for $2 \mathrm{wk}$ with G418 $(800 \mu \mathrm{g} / \mathrm{ml})$, supplemented after 1 wk with $160 \mathrm{nM}$ vincristine. $2 \mathrm{wk}$ after the transfection, selection was reduced to $40 \mathrm{nM}$ vincristine only. LLC-MDR1 (21) was obtained by transfecting LLCPK1 cells with the expression vector pFRCMVMDR1.1 (24), containing a human MDR1 cDNA. S1(MRP) and S1(MDR1) are transfectants of the non-small cell lung cancer cell line SW-1573/S1 that overexpress either human $M R P$ or $M D R 1$ cDNAs $(4,14)$.

Immunocytochemistry. Cells were grown on microporous polycarbonate membrane filters $(3.0 \mu \mathrm{m}$ pore size, $24.5 \mathrm{~mm}$ diameter, Transwell ${ }^{\mathrm{TM}} 3414$; Costar Corp., Cambridge, MA) at a density of $2 \times$ $10^{6}$ cells per well. Cells were grown for $3 \mathrm{~d}$ with one medium replacement. For confocal laser scanning microscopy, cells were washed in PBS and fixed for $10 \mathrm{~min}$ in 3\% (vol/vol) formaldehyde in PBS, followed by permeabilization with $1 \%$ (vol/vol) Triton X-100 for $5 \mathrm{~min}$. Filters were incubated for 60 min with mAb MRPr1 (1:500; 5). Antibody binding was detected with a FITC-labeled rabbit anti-rat IgG (1:50; Nordic, Tilburg, The Netherlands). The filters were mounted with Vectashield (Vector Laboratories, Burlingame, CA) containing propidiumiodide $(1 \mu \mathrm{g} / \mathrm{ml})$ for counterstaining of nucleic acids. Cells were examined with a MRC-600 confocal microscope (Bio Rad, Hertfordshire, UK) coupled to a Nikon microscope equipped with a $\times 60$ objective. For immunoelectron microscopy, cells were grown on glass slides precoated with formvar and fixed in $4 \%$ (wt/vol) paraformaldehyde and $0.5 \%$ ( $\mathrm{vol} / \mathrm{vol})$ glutaraldehyde in $0.1 \mathrm{M}$ phosphate buffer, $\mathrm{pH}$ 7.2. Cells and formvar were removed together from the slide and embedded in $10 \%$ (wt/vol) gelatin in PBS. Ultrathin frozen sections were incubated with mAb MRPr1 (1:100), followed by rabbit anti-rat IgG (1:40) and goat anti-rabbit IgG (1:40) linked to 10-nm gold particles (Amersham, Den Bosch, The Netherlands). Incubations were for $1 \mathrm{~h}$ at room temperature. After immunolabeling, the cryosections were embedded in methylcellulose/uranylacetate and examined with a Philips CM 10 electron microscope (Philips, Eindhoven, The Netherlands).

Transport assays. $\left[{ }^{3} \mathrm{H}\right]$ daunorubicin transport assays were carried out as described (21). Briefly, cells were seeded on microporous polycarbonate filters (see immunocytochemistry) at a density of $2 \times 10^{6}$ cells per well and grown for $3 \mathrm{~d}$. Experiments were started $(\mathrm{t}=0)$ by replacing the medium at either the apical or the basolateral side of the monolayer with $2 \mathrm{ml}$ of medium containing the appropriate concentration of radiolabeled daunorubicin (at $0.25 \mu \mathrm{Ci} / \mathrm{ml}, 2 \mu \mathrm{M}$ ), and ${ }^{14} \mathrm{C}$-labeled inulin $(0.025 \mu \mathrm{Ci} / \mathrm{ml}, 4.2 \mu \mathrm{M})$. The cells were incubated at $37^{\circ} \mathrm{C}$ in $5 \% \mathrm{CO}_{2}$, and $50-\mu \mathrm{l}$ aliquots were taken from each compartment at 1,2,3, and $4 \mathrm{~h}$. The appearance of radioactivity in the opposite compartment was measured and presented as the fraction of total radioactivity added at the beginning of the experiment. The paracellular flux was monitored by the appearance of inulin- $\left[{ }^{14} \mathrm{C}\right]$ carboxylic acid in the opposite compartment and was always $<1.5 \%$ of total radioactivity per h. For determination of intracellular $\left[{ }^{3} \mathrm{H}\right]$ daunorubicin accumulation at the end of the $4 \mathrm{~h}$ transport experiment filters were washed with cold PBS, excised and integrally counted in liquid scintillation vials. Accumulation data for initial administration at either apical or basal side were pooled.

Export of GS- $\left[{ }^{14} \mathrm{C}\right] \mathrm{DNP}$ (GSH $S$-dinitrophenyl) from cells was determined by incubating cells with $\left[{ }^{14} \mathrm{C}\right] \mathrm{CDNB}$. $\left[{ }^{14} \mathrm{C}\right] \mathrm{CDNB}$ was dissolved in dimethyl sulfoxide to a concentration of $10 \mathrm{mM}$ and diluted in medium $\left(23^{\circ} \mathrm{C}\right)$ to a concentration of $2 \mu \mathrm{M}$ just before the start of the experiment. $2 \mathrm{ml}$ of medium containing $\left[{ }^{14} \mathrm{C}\right] \mathrm{CDNB}$ was applied to both the apical and basal compartment of the monolayer and 200 $\mu \mathrm{l}$ aliquots were taken at various time points. As excretion of GS$\left[{ }^{14} \mathrm{C}\right] \mathrm{DNP}$ was extremely rapid at $37^{\circ} \mathrm{C}$, incubations were done at $23^{\circ} \mathrm{C}$. Samples were immediately extracted with $200 \mu$ l of ethylacetate and centrifuged for $2 \mathrm{~min}(12,000 \mathrm{~g})$. Radioactivity in $160 \mu \mathrm{l}$ of both phases was determined by liquid scintillation counting. The amount of radioactivity was corrected for the decrease in volume of the culture medium. In case inhibitors were used during the incubation period, cells were first incubated with medium containing the appropriate concentration of inhibitor at $37^{\circ} \mathrm{C}$ in $5 \% \mathrm{CO}_{2}$ for $10 \mathrm{~min}$. To determine intracellular GS- $\left[{ }^{14} \mathrm{C}\right] \mathrm{DNP}$, cells were washed with cold PBS, filters were cut from the plate and cells were lysed by the addition of $10 \%(\mathrm{vol} / \mathrm{vol})$ perchloric acid. After centrifugation the supernatant was neutralized by adding 0.4 volumes of $3 \mathrm{M} \mathrm{KOH} / 0.5 \mathrm{M}$ Mops and centrifuged again. The supernatant was extracted with an equal volume of ethylacetate and radioactivity in both phases was determined by liquid scintillation counting. Alternatively, GS- $\left[{ }^{14} \mathrm{C}\right] \mathrm{DNP}$ in the cells was determined by counting the filters directly in liquid scintillation fluid, after washing with cold PBS. Comparison between both methods showed that $70-90 \%$ of radioactivity directly measured in cells on filters was extractable GS- $\left[{ }^{14} \mathrm{C}\right] \mathrm{DNP}$.

\section{Results}

Generation of LLC-PK1 cells expressing human MRP. To study transport properties of MRP we transfected a human $M R P$ cDNA expression vector (4) into the polarized pig kidney epithelial cell line LLC-PK1. RNase protection using a probe for the human $M R P$ cDNA confirmed that one selected clone contained a high level of $M R P$ RNA, whereas no human $M R P$ RNA was detected in parental LLC-PK1 cells or in LLC-MDR1 cells (data not shown). The $M R P$-overexpressing transfectant (LLC-MRP) was threefold resistant to vincristine compared to the untransfected LLC-PK1 cells in a clonogenic survival assay.

Western blot analysis of crude membrane fractions of LLC-PK1 cells, LLC-MRP, and LLC-MDR1 with the mAb

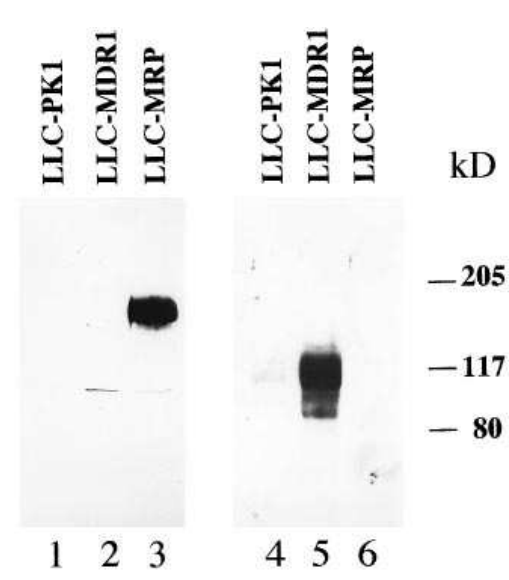

Figure 1. MRP and MDR1 levels in crude membrane fractions from LLC-PK1 derived clones. $20 \mu \mathrm{g}$ of protein was size fractionated in a $7.5 \%(\mathrm{wt} /$ vol) polyacrylamide gel containing $0.1 \%$ (wt/vol) SDS. After electroblotting, MRP was visualized by staining with $\mathrm{mAb}$ MRPr1 (lanes 1-3), MDR1 by staining with $\mathrm{mAb}$ C219 (lanes 4-6). The identity of the cell lines analyzed is indicated over the lanes. 
MRPr1 (5) revealed that LLC-MRP contained a substantial amount of MRP (Fig. 1, lanes 1-3). We were unable to detect MRP in the parental LLC-PK1 or in LLC-MDR1 cells, even after prolonged exposure under conditions where the basal level of MRP in human SW-1573 lung cancer cells was easily detectable (data not shown). As MRP appears to be ubiquitously expressed in human cell lines, we assume that the $\mathrm{mAb}$ MRPr1 does not cross-recognize the endogenous porcine homologue of MRP. Incubation of the same blot with mAb C219 demonstrated that Pgp was readily detectable in LLC-MDR1 cells (Fig. 1, lane 5). Long exposure revealed the low basal level of Pgp present in LLC-PK1 and LLC-MRP cells, and demonstrated that there was no increase in endogenous Pgp level in LLC-MRP cells (not shown).

Immunolocalization of MRP. To investigate the subcellular localization of MRP, LLC-MRP, and LLC-PK1 cells were grown to confluency on microporous membrane filters to establish optimal polarization, and MRP was visualized by indirect immunofluorescence using confocal laser-scanning microscopy. A top view of the epithelial cell layer shows a clear staining of the plasma membranes of the LLC-MRP cells with mAb MRPr1 (Fig. $2 A$ ), whereas the parental LLC-PK1 cells hardly stained at all (Fig. $2 \mathrm{~B}$ ). Weak staining was observed in the cytoplasm of LLC-MRP cells, possibly representing a low level of MRP in intracellular membranes. Unexpectedly, examination of the cells at the plane perpendicular to the membrane filter showed that almost all MRP immunostaining was confined to the lateral membranes, whereas the apical membranes did not show significant staining (Fig. 2 A, lower rectangular panel).

The lateral localization of MRP was confirmed by immunoelectron microscopy. Ultrathin frozen sections of LLC-MRP cells and LLC-PK1 cells were cut perpendicular with respect to the cell layer and incubated with mAb MRPr1, followed by rabbit anti-rat IgG and goat anti-rabbit IgG linked to $10-\mathrm{nm}$ gold particles. A typical picture is shown in Fig. 3 A. Gold particles were mainly confined to the basolateral membrane, although some particles were also visualized on the apical membrane, in the cytosol, and in mitochondria. Whereas no basolateral staining was found in parental LLC-PK1 cells,

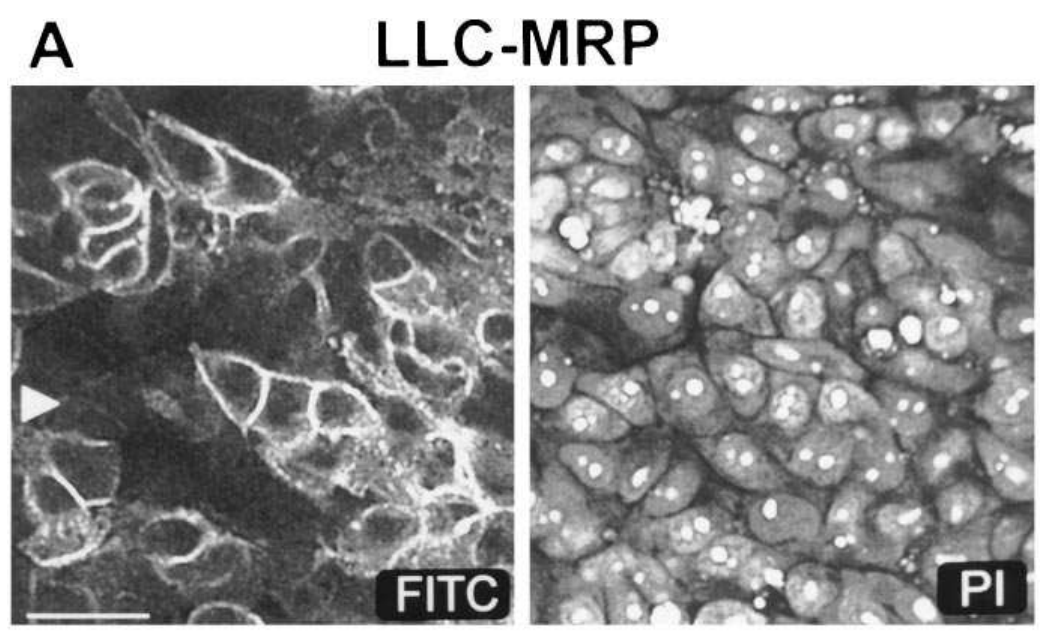

0.11 13int is

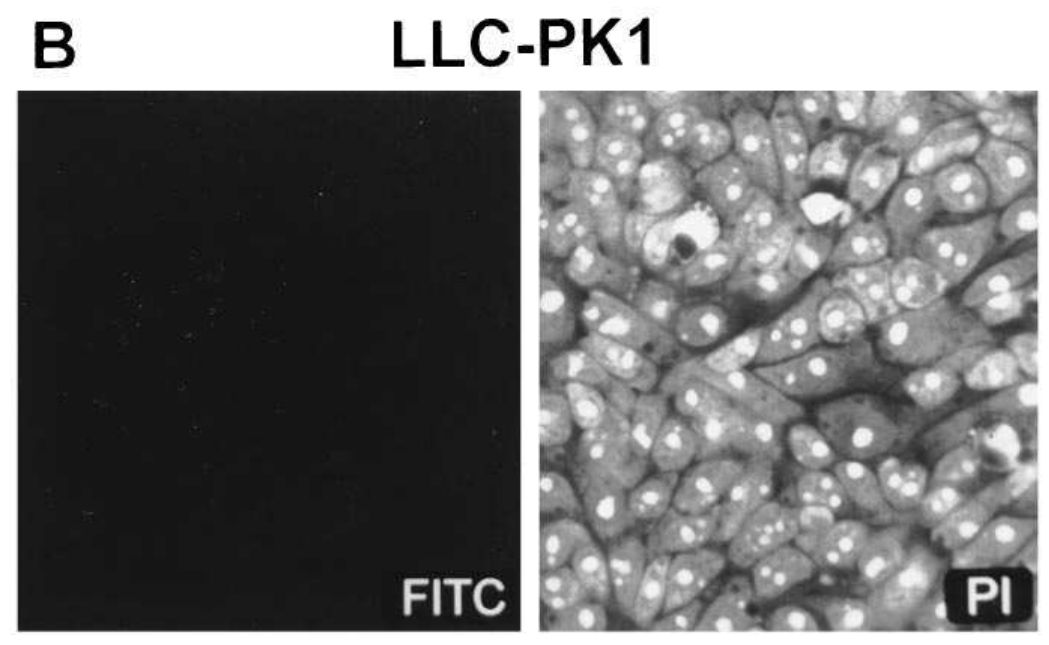

Figure 2. Detection of human MRP in LLC-MRP monolayers by confocal laser-scanning microscopy. (A) Left: Indirect immunofluorescence (FITC) picture with mAb MRPr1 on LLC-MRP cells. Top view of the cell layer. Right: The corresponding propidium iodide $(P I)$ picture. Lower part: Optical section perpendicular to the plane of the cell layer. Arrow head in the top indicates the position of this section. Heterogeneity in immunostaining between individual cells probably reflects differences in expression levels. (B) Same as $A$, but for LLC-PK1 parental cells. The bar is $25 \mu \mathrm{m}$. 


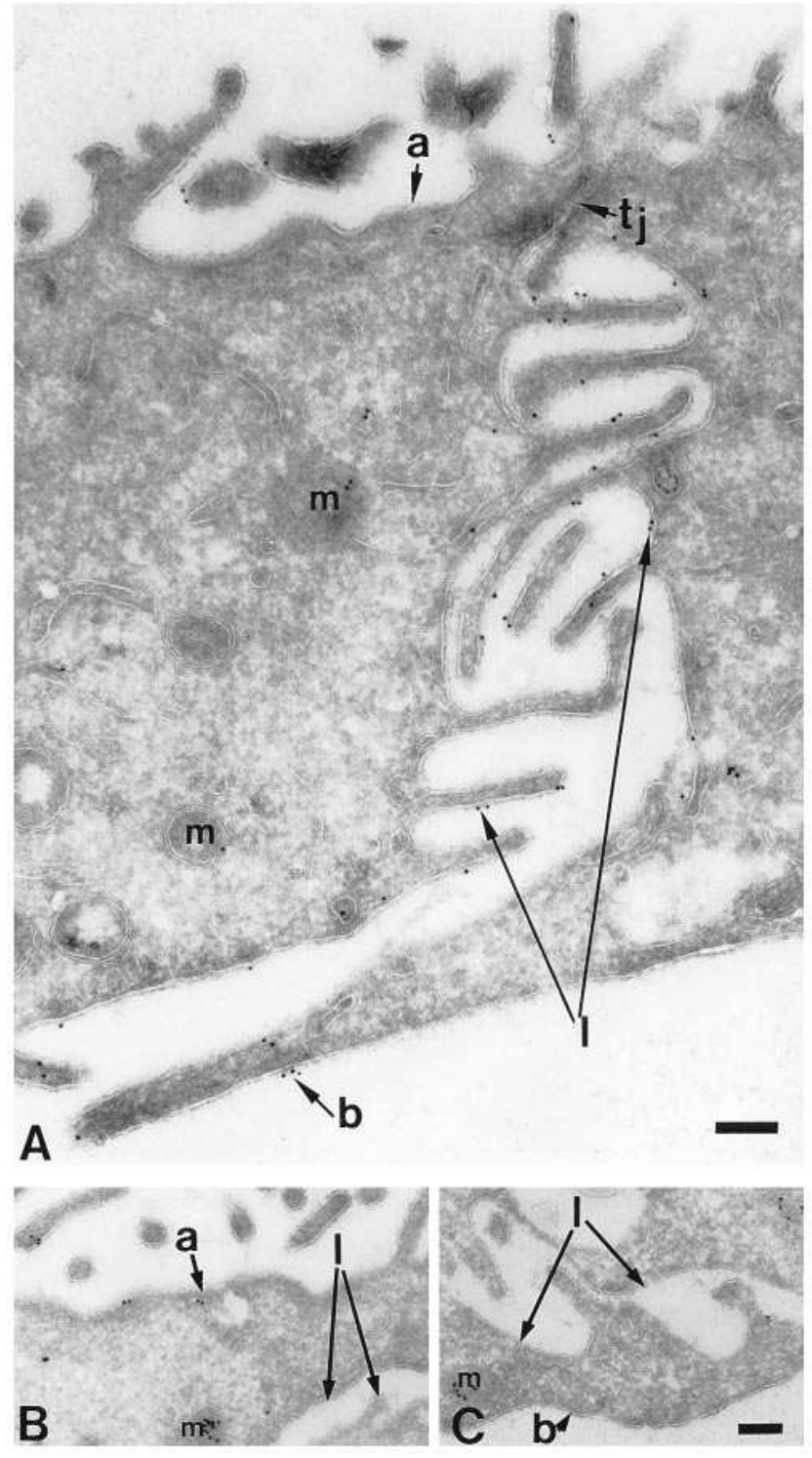

Figure 3. Detection of MRP in ultrathin cryosections of LLC-MRP cells by immunoelectron microscopy. ( $A$ ) Section of LLC-MRP cells labeled with mAb MRPr1 to detect MRP, showing at the top the apical surface $(a)$, separated from the lateral $(l)$ and basal $(b)$ surface by a tight junction $(t j)$. Most gold particles were detected on the lateral membrane. ( $B$ and $C$ ) Same as $A$, but with LLC-PK1 parental cells. No labeling was detected on the lateral $(l)$ and basal $(b)$ membranes. Some background labeling was present on the apical surface $(a)$ and in the cytosol. High background was observed in mitochondria $(m)$, due to the secondary antibody used. The bars are $200 \mathrm{~nm}$.

some apical and mitochondrial signals were also observed in these cells, suggesting that they were due to background binding (Fig. $3 B$ and $C$ ).

Export of dinitrophenyl-glutathione by LLC-MRP cells. Jedlitschky et al. (7) and Müller et al. (8) showed that dinitrophenyl-glutathione (GS-DNP) is transported into membrane vesicles prepared from $M R P$-overexpressing cells. To investigate whether GS-DNP is also a substrate for MRP in intact cells, transport was analyzed in LLC-PK1, LLC-MDR1, and LLC-MRP cells. We used $\left[{ }^{14} \mathrm{C}\right] \mathrm{CDNB}$, a hydrophobic compound that easily diffuses into cells and is subsequently conju- gated by cellular glutathione $S$-transferases with GSH, resulting in GS-DNP. This charged compound cannot leave the cell, except by mediated transport. We used extraction with ethylacetate to separate unconjugated hydrophobic $\left[{ }^{14} \mathrm{C}\right] \mathrm{CDNB}$ from hydrophilic GS- $\left[{ }^{14} \mathrm{C}\right] \mathrm{DNP}$ accumulating in the medium, or in the cells. It has been shown by HPLC analysis that the only metabolite of CDNB formed within a mammalian cell line is GS-DNP and that the primary metabolite excreted by cells incubated with $\left[{ }^{14} \mathrm{C}\right] \mathrm{CDNB}$ is $\mathrm{GS}-\left[{ }^{14} \mathrm{C}\right] \mathrm{DNP}$ (25; data not shown).

To distinguish transport of GS- $\left[{ }^{14} \mathrm{C}\right] \mathrm{DNP}$ across the apical membrane (apical transport) from transport across the basolateral membrane (basolateral transport), cells were allowed to form a tight epithelial monolayer on microporous membrane filters. Under these conditions, substrates pumped across the apical membrane accumulate in the apical compartment, whereas substrates pumped across the basolateral membrane accumulate in the basal compartment.

Analysis of GS- $\left[{ }^{14} \mathrm{C}\right] \mathrm{DNP}$ export in LLC-PK1 derived cells was complicated by the presence of substantial levels of endogenous GS- $\left[{ }^{14} \mathrm{C}\right] \mathrm{DNP}$ transporters in both apical and basal membranes of these cells. In fact, in all cell lines the GS$\left[{ }^{14} \mathrm{C}\right] \mathrm{DNP}$ export rate at $37^{\circ} \mathrm{C}$ was so rapid, that it was limited by the rate of cellular GS- $\left[{ }^{14} \mathrm{C}\right] \mathrm{DNP}$ synthesis (data not shown). Only by lowering the temperature to $23^{\circ} \mathrm{C}$ we could find conditions that allowed the formation of a substantial intracellular pool of GS-[ $\left[{ }^{14} \mathrm{C}\right] \mathrm{DNP}$ in LLC-PK1 and LLC-MDR1 cells, but not in LLC-MRP cells (Table I). The 10-fold lower level of GS- $\left[{ }^{14} \mathrm{C}\right] \mathrm{DNP}$ in LLC-MRP cells was suggestive for a more efficient export of this compound from these cells. Under these conditions, polarized GS- $\left[{ }^{14} \mathrm{C}\right] \mathrm{DNP}$ export in LLCPK1 and LLC-MDR1 cells was mainly limited by the rate of transport, whereas in LLC-MRP cells the GS- $\left[{ }^{14} \mathrm{C}\right] \mathrm{DNP}$ export was still primarily limited by the rate of GS- $\left[{ }^{[4} \mathrm{C}\right] \mathrm{DNP}$ synthesis. The resulting pattern of GS- $\left[{ }^{14} \mathrm{C}\right] \mathrm{DNP}$ export is illustrated in Fig. $4 A$ : all three cell lines demonstrated preferential GS$\left[{ }^{14} \mathrm{C}\right] \mathrm{DNP}$ export to the basal compartment, but basolateral transport (10-20 min) in LLC-MRP was 1.6-fold higher, and apical transport was twofold lower than in LLC-PK1 and LLCMDR1 cells.

The total amount of GS- $\left[{ }^{14} \mathrm{C}\right] \mathrm{DNP}$ retrieved in cells and medium together after 20 min was similar in LLC-PK1, LLCMDR1, and LLC-MRP, demonstrating that all cells had comparable GSH $S$-transferase activity (combined data of Fig. $4 \mathrm{~A}$

Table I. Accumulation of GS- $\left[{ }^{14} C\right] D N P$ in LLC-PK1 Derived Cell Lines after Incubation for 20 min with $\left[{ }^{14} C\right] C D N B$ in the Absence or Presence of Increasing Concentrations of Sulfinpyrazone

\begin{tabular}{lcccc}
\hline & \multicolumn{4}{c}{ GS- $\left[{ }^{14} \mathrm{C}\right] \mathrm{DNP}$, nanomoles per $2 \times 10^{6}$ cells } \\
\cline { 2 - 5 } & \multicolumn{4}{c}{ Sulfinpyrazone $(\mathrm{mM})$} \\
\hline Cell line & - & 1 & 2 & 4 \\
LLC-PK1 & $1.40 \pm 0.13$ & $2.89 \pm 0.11$ & $3.47 \pm 0.11$ & $3.55 \pm 0.03$ \\
LLC-MDR1 & $1.48 \pm 0.04$ & $1.70 \pm 0.03$ & $2.15 \pm 0.02$ & $3.23 \pm 0.15$ \\
LLC-MRP & $0.16 \pm 0.01$ & $1.08 \pm 0.06$ & $2.35 \pm 0.04$ & $2.92 \pm 0.10$
\end{tabular}

Numbers are the mean of two experiments. Variation between measurements is indicated. 

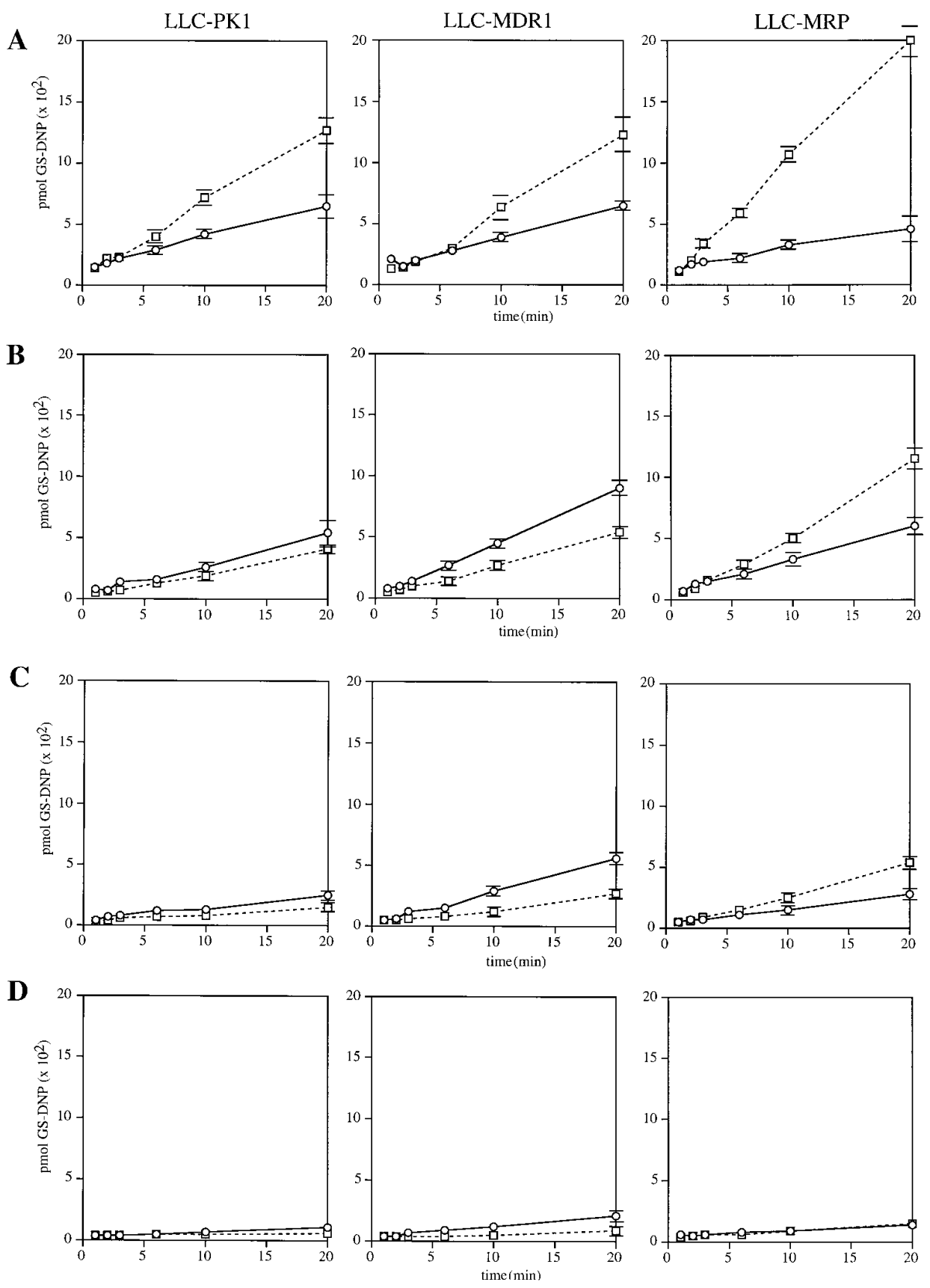

Figure 4. Polarized export of GS$\left[{ }^{14} \mathrm{C}\right] \mathrm{DNP}$ from LLC-PK1, LLCMDR1, and LLC-MRP monolayers. (A) Cells were incubated with $\left[{ }^{14} \mathrm{C}\right] \mathrm{CDNB}(2 \mu \mathrm{M})$ in both the apical and basal compartments. Samples were taken at $\mathrm{t}=1,2,3,6,10$, and $20 \mathrm{~min}$ from basolateral and apical compartments and extracted with ethylacetate. The amount of GS- $\left[{ }^{14} \mathrm{C}\right] \mathrm{DNP}$ excreted (in pmol per $2 \mathrm{ml}$ ) was measured and plotted. All experiments were done in duplicate and repeated at least twice. Small bars around the average value indicate the range of measured values. Where variation was small bars are omitted. Dotted line and $\square$ : transport to the basal compartment. Continuous line and $\bigcirc$ : transport to the apical compartment. $(B-D)$ Cells were preincubated with increasing concentrations of sulfinpyrazone in both compartments (1, 2 , and $4 \mathrm{mM}$, respectively) for 10 min. At $\mathrm{t}=0\left[{ }^{14} \mathrm{C}\right] \mathrm{CDNB}$ was added to both compartments and samples were taken and analyzed as described for $A$. and Table I). The intracellular level of GS- $\left[{ }^{[4} \mathrm{C}\right] \mathrm{DNP}$ after 10 min was similar to that after $20 \mathrm{~min}$ in LLC-MRP, and again 5-10-fold lower than in LLC-PK1 and in LLC-MDR1 (data not shown). These data strongly suggest that the GS- $\left[{ }^{14} \mathrm{C}\right] \mathrm{DNP}$ export in LLC-MRP was primarily limited by the rate of formation of intracellular GS- $\left[{ }^{[4} \mathrm{C}\right] \mathrm{DNP}$, whereas in the LLCPK1 and LLC-MDR1 cells the export capacity was limiting. It is therefore likely that the basolateral export rate as measured in Fig. $4 A$ for LLC-MRP substantially underestimates the difference in potential GS-DNP export capacity with the other two cell lines.

These experiments showed that overexpression of $M R P$ is correlated with increased basolateral glutathione $S$-conjugate export activity. To test whether this transport system resembles the GS-X pump, we used sulfinpyrazone, a well known in- hibitor of organic anion transport (26). In the presence of 1 $\mathrm{mM}$ sulfinpyrazone the basolateral efflux of GS- $\left[{ }^{[4} \mathrm{C}\right] \mathrm{DNP}$ decreased in all three cell lines, but it remained two to threefold higher in LLC-MRP. The apical transport was only slightly decreased (LLC-PK1), or even somewhat increased (LLCMDR1, LLC-MRP; Fig. 4 B). At higher sulfinpyrazone concentrations ( 2 and $4 \mathrm{mM}$; Fig. $4 C$ and $D$, respectively) both basolateral and apical GS- $\left[{ }^{14} \mathrm{C}\right] \mathrm{DNP}$ export were clearly reduced, nearly reaching background at $4 \mathrm{mM}$. However, LLC-MRP maintained a higher basolateral export activity over the whole range of sulfinpyrazone concentrations compared to the other cell lines. At $4 \mathrm{mM}$ sulfinpyrazone LLC-MDR1 cells were still able to efficiently transport daunorubicin (see below and data not shown), indicating that the reduction in transport of GS$\left[{ }^{14} \mathrm{C}\right] \mathrm{DNP}$ was not the result of generalized toxicity, e.g., by de- 
pletion of the cellular ATP-pool by this concentration of sulfinpyrazone. The observed reduction in GS- $\left[{ }^{14} \mathrm{C}\right] \mathrm{DNP}$ export activity was not due to the inhibition of GSH $S$-transferase activity by sulfinpyrazone either, as proportionally more intracellular GS- $\left[{ }^{14} \mathrm{C}\right] \mathrm{DNP}$ accumulated when the cells were treated with increasing concentrations of sulfinpyrazone (Fig. 4 and Table I). Indeed, the total amount of GS- $\left[{ }^{14} \mathrm{C}\right] \mathrm{DNP}$ detected after $20 \mathrm{~min}$ in cells and medium combined remained comparable at all sulfinpyrazone concentrations. Probenecid, another well-known inhibitor of organic anion transport (27) produced similar effects as sulfinpyrazone, although $10 \mathrm{mM}$ was needed to get an effect comparable to that found with 1 $\mathrm{mM}$ sulfinpyrazone (data not shown).

Basolateral transport of $\left[{ }^{3} H\right]$ daunorubicin by $L L C-M R P$ cells. Vectorial transport of the cytostatic drug daunorubicin was also studied in LLC-PK1, LLC-MDR1, and LLC-MRP cells. In these experiments $\left[{ }^{3} \mathrm{H}\right]$ daunorubicin $(2 \mu \mathrm{M})$ was added on either the apical or the basolateral side of the cell layer, and the accumulation of radioactivity in the opposite compartment was followed. As $\left[{ }^{3} \mathrm{H}\right]$ daunorubicin can rather easily diffuse across membranes, the detected translocation of radioactivity is a combination of passive diffusion of $\left[{ }^{3} \mathrm{H}\right]$ daunorubicin across the epithelial cell layer and active transport of $\left[{ }^{3} \mathrm{H}\right]$ daunorubicin and derived metabolites. Fig. $5 \mathrm{~A}$ shows that LLC-MRP cells transported significantly more $\left[{ }^{3} \mathrm{H}\right]$ daunorubicin towards the basolateral side than the parental LLC-PK1 cells. In contrast, $M D R 1$-transfected cells demonstrated a high level of transport towards the apical side, effective enough to diminish the flow of $\left[{ }^{3} \mathrm{H}\right]$ daunorubicin towards the basolateral side. Similar results were obtained in three independent experiments, and also when 50 or $500 \mathrm{nM}\left[{ }^{3} \mathrm{H}\right]$ daunorubicin was used (data not shown). Measurement of total radioactivity in the cells after the $4 \mathrm{~h}$ incubation with $\left[{ }^{3} \mathrm{H}\right]$ daunorubicin $(n=4)$ showed that LLC-PK1 cells contained an average of $15.6 \pm 2.6 \%$ of the total applied amount of $\left[{ }^{3} \mathrm{H}\right]$ daunorubicin, LLC-MDR1 cells $0.7 \pm 0.3 \%$, and LLC-MRP cells $7.6 \pm 1.0 \%$, indicating decreased accumulation of $\left[{ }^{3} \mathrm{H}\right]$ daunorubicin in both $M R P$ - and $M D R 1$-expressing cells.

Addition of $1 \mathrm{mM}$ sulfinpyrazone in the $\left[{ }^{3} \mathrm{H}\right]$ daunorubicin transport assay caused inhibition of transport to the basolateral side in LLC-MRP cells, but also somewhat in LLC-PK1 cells (Fig. 5 B). Transport in LLC-MDR1 cells was not affected. The average cellular accumulation of $\left[{ }^{3} \mathrm{H}\right]$ daunorubicin in the presence of sulfinpyrazone was $16.7 \pm 3.3 \%$ in LLC-PK1 cells, $0.8 \pm 0.5 \%$ in LLC-MDR1 cells, and $13.3 \pm 2.5 \%$ in LLCMRP cells, indicating increased accumulation in LLC-MRP cells, but not in LLC-MDR1 cells. Comparable cellular concentrations were obtained with $2 \mathrm{mM}$ sulfinpyrazone. 2.5 or 10 $\mathrm{mM}$ of probenecid had similar, although somewhat less pronounced, effects on $\left[{ }^{3} \mathrm{H}\right]$ daunorubicin transport in these cell lines as $1 \mathrm{mM}$ sulfinpyrazone (data not shown).

\section{Discussion}

This study shows that the human MRP is predominantly routed to the basolateral membrane of LLC-PK1 pig kidney epithelial cells, where it mediates preferential transport of the glutathione $S$-conjugate GS-DNP, and of the anticancer drug daunorubicin to the basal side of the cell layer. This MRPmediated transport to the basal side is specifically inhibited by probenecid and sulfinpyrazone, compounds that do not detectably affect the MDR1 Pgp-mediated transport of daunorubicin to the apical side. Our results confirm that MRP can increase the export of a GSH $S$-conjugate from living cells, as was predicted from previous in vitro experiments $(7,8)$. We do not know whether daunorubicin is transported by MRP as a shortlived complex with, e.g., GSH, or as unchanged drug. Previous experiments with $M R P$-overexpressing cells indicate that a putative transported daunorubicin-GS complex (if it exists at all) is too short-lived in medium for HPLC detection (14). Attempts to demonstrate MRP-mediated polarized transport of other MRP substrate anticancer drugs in LLC-MRP cells
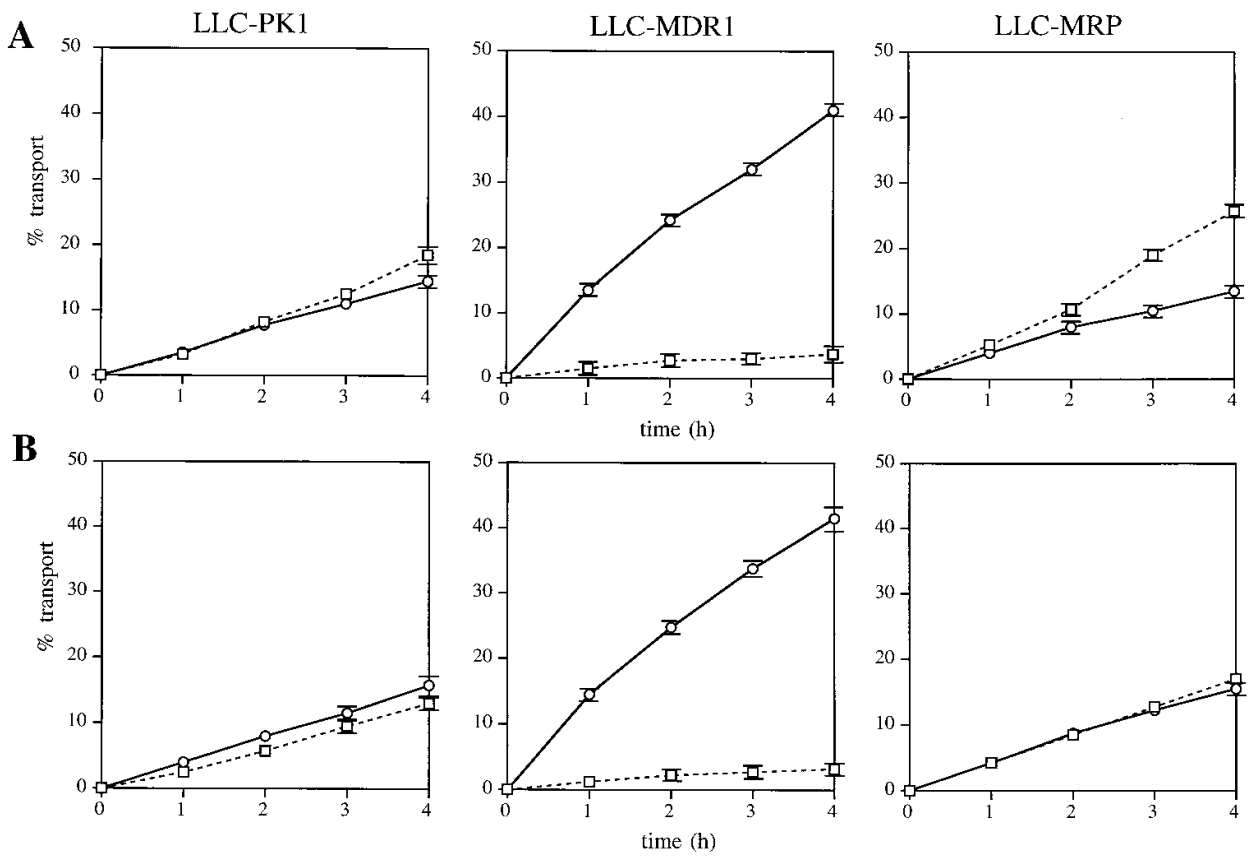

Figure 5. Transepithelial transport of $\left[{ }^{3} \mathrm{H}\right]$ daunorubicin in LLC-PK1, LLC-MDR1, and LLC-MRP monolayers. $(A)$ At $\mathrm{t}=0\left[{ }^{3} \mathrm{H}\right]$ daunorubicin was applied in one compartment (basal or apical), and the percentage of radioactivity appearing subsequently in the opposite compartment was measured and plotted. Samples were taken at $\mathrm{t}=1,2,3$, and $4 \mathrm{~h}$. Experiments were done in duplicate. Small bars around the average value indicate the measured values. Where variation was small bars are omitted. Dotted line and $\square$ : translocation from the apical to the basal compartment. Continuous line and $\bigcirc$ : translocation from the basal to the apical compartment. ( $B$ ) Same as $A$, but $\left[{ }^{3} \mathrm{H}\right]$ daunorubicin transport was measured in the presence of $1 \mathrm{mM}$ sulfinpyrazone in both the apical and basal compartment. 
failed for various reasons: vincristine and etoposide did not enter the cells fast enough to perform reliable transport studies, and vinblastine translocation was dominated by the endogenous pig Pgp.

Our findings indicate that sulfinpyrazone and probenecid are relatively specific inhibitors of MRP-mediated transport of daunorubicin that do not affect MDR1-mediated transport. Therefore, we have also tested whether these compounds could reverse the MRP-mediated vincristine resistance of SW1573 human lung cancer cells transfected with an $M R P$ cDNA (4). Preliminary results indicate that these compounds can indeed partially reverse vincristine resistance in S1(MRP) cells, but not in SW-1573 cells overexpressing MDR1. However, reversal was partial, and both sulfinpyrazone and probenecid had to be used at near-toxic dosages. Nevertheless, high doses of both compounds have been used clinically (28), so if MRP contributes to clinical drug resistance of tumors, they might be useful lead compounds for the development of less toxic and more specific reversal agents.

The basolateral localization of MRP came as a surprise to us, as we had expected an excretory function of this class of protein in the intact organism, which would be more compatible with an apical localization, as found for the MDR1 Pgp. Nevertheless, all experiments, including immunolight microscopy, immunoelectron microscopy, and the transport studies, confirm the basolateral localization. LLC-PK1 cells perform regular polarized sorting of membrane proteins, as was previously shown for instance by the correct basolateral routing of the $\mathrm{Na}$, K-ATPase, and the proper apical routing of the related H, K-ATPase (29). Human MDR1 and mouse mdr1a P-glycoprotein are also correctly routed to the apical membrane in these cells $(20,21)$. We therefore think that MRP is properly sorted in LLC-PK1 cells. Sorting to either apical or basolateral plasma membranes is mediated by specific signals in proteins (for review see reference 30). Although amino acid residues important for basolateral sorting have been identified in the cytosolic tail of several single-spanning membrane proteins, no definitive consensus sequence has been clarified yet (for review see reference 31 ). Whether multispanning membrane proteins like MRP (or Pgp) use similar signals remains to be seen.

It is interesting to note that the endogenous GS-DNP export activity found in LLC-PK1 cells also demonstrates preferential transport to the basal side (Fig. $4 \mathrm{~A}$ ), and that this basolateral transport activity is relatively more sensitive to sulfinpyrazone (and probenecid) than the apical GS-DNP transport activity (Fig. $4 \mathrm{~B}$ ). The MRP-mediated basolateral transport in LLC-MRP is also more sensitive to sulfinpyrazone than the (endogenous) apical transport (Fig. 4 B). Only at higher sulfinpyrazone concentrations were both apical and basolateral transport efficiently blocked (Fig. 4, $C$ and $D$ ). Preferential, ATP-dependent, basolateral transport of GS-DNP was previously also found in polarized human Caco- 2 colon carcinoma epithelial cells (25). That MRP could be involved in GS-DNP transport in these cells is suggested by Western blot analysis, which showed the presence of MRP in Caco- 2 cells, albeit at a low level (data not shown).

These findings lead us to propose that there exist at least two different endogenous GS-DNP transport systems in the LLC-PK1 parental cells, one with an apical localization and somewhat lower sensitivity to sulfinpyrazone, and another with a basolateral localization and somewhat higher sensitivity to sulfinpyrazone. Based on the cellular localization and the sensitivity to sulfinpyrazone, the human MRP seems to be more closely related to the latter transport system, which might represent a pig homologue of MRP. Other researchers have also found indications for the coexistence of multiple distinct ATP-dependent GS-DNP transport systems in one cell line (e.g., 32). Multiplicity of MRP-like transporters is further suggested by the recent entry of four $M R P$-like partial human cDNA sequences in the GenBank/EMBL database. Moreover, Oude Elferink et al. (33) demonstrated that the $\mathrm{TR}^{-}$mutant rat strain, which is deficient in the bile canalicular excretion of GS-DNP performed by hepatocytes of normal rats, still performs normal (and saturable) GS-DNP transport across the sinusoidal membrane of hepatocytes. This finding further supports the existence of at least two distinguishable GS-DNP export systems. As the hepatocyte sinusoidal membrane is in many respects comparable to the basolateral membrane of epithelial cells, the GS-DNP export system not affected in $\mathrm{TR}^{-}$ rats appears to be sorted to the basolateral membrane domain, just like MRP in LLC-PK1 cells. The basolateral or sinusoidal GS-DNP transporter of rats might therefore represent a rat homologue of the human MRP.

It is tempting to speculate about a possible relationship between the probenecid- and sulfinpyrazone-inhibitable excretion of organic anions in the kidney and MRP. Based on the presence of several markers, LLC-PK1 cells are probably derived from the proximal part of the kidney tubules (34). Unfortunately, in contrast to the extensive studies done in the liver, not much is known about GS-X pump activities in the kidney. Excretion of organic anions by the kidney is relatively complicated, and so far a basolateral uptake system and a lumenal organic anion exchange system have been detected in proximal tubular epithelia of the kidney (35). Together, these systems appear to be responsible for the excretion, but sometimes also for tubular resorption, of organic anions. To our knowledge, no basolateral (or apical) GS-X pump activity has been identified in these cells yet. This may mean that GS-X pumps are not important for kidney excretory function, or, alternatively, that they have been missed in the analyses carried out so far. $M R P$ expression is found in human kidney (15). Hence, future analysis of kidney function might reveal a relevant contribution of MRP to the excretion or resorption of organic anions.

\section{Acknowledgments}

We thank our colleagues for critical comments on the manuscript. We are indebted to Dr. V. Ling (B. C. Cancer Research Center, Vancouver, Canada) and Dr. S. Warnaar (Centocor Europe, Leiden, The Netherlands) for providing mAb C219.

This work was supported in part by grants from the European Union (ERBCIPACT 930265 to P. Borst and A.H. Schinkel), the Dutch Cancer Society (NKI 92-41 to P. Borst), and by a collaborative project of the Netherlands Cancer Institute and the University of Amsterdam (to P. Borst).

\section{References}

1. Gottesman, M.M., and I. Pastan. 1993. Biochemistry of multidrug resistance mediated by the multidrug transporter. Annu. Rev. Biochem. 62:385-427.

2. Cole, S.P.C., G. Bhardwaj, J.H. Gerlach, J.E. Mackie, C.E. Grant, K.C Almquist, A.J. Stewart, E.U. Kurz, A.M.V. Duncan, and R.G. Deeley. 1992. Overexpression of a transporter gene in a multidrug-resistant human lung cancer cell line. Science (Wash. DC). 258:1650-1654.

3. Cole, S.P.C., K.E. Sparks, K. Fraser, D.W. Loe, C.E. Grant, G.M. Wilson, 
and R.G. Deeley. 1994. Pharmacological characterization of multidrug resistant MRP-transfected human tumor cells. Cancer Res. 54:5902-5910.

4. Zaman, G.J.R., C.H.M. Versantvoort, J.J.M. Smit, E.W.H.M. Eijdems, M. de Haas, A.J. Smith, H.J. Broxterman, N.H. Mulder, E.G.E. de Vries, F. Baas, and P. Borst. 1994. The human multidrug resistance-associated protein MRP is a plasma membrane drug-efflux pump. Proc. Natl. Acad. Sci. USA. 91: 8822-8826.

5. Flens, M.J., M.A. Izquierdo, G.L. Scheffer, J.M. Fritz, C.J.L.M. Meijer, R.J. Scheper, and G.J.R. Zaman. 1994. Immunochemical detection of the multidrug resistance-associated protein MRP in human multidrug-resistant tumor cells by monoclonal antibodies. Cancer Res. 54:4557-4563.

6. Almquist, K.C., D.W. Loe, D.R. Hipfner, J.E. Mackie, S.P.C. Cole, and R.G. Deeley. 1995. Characterization of the Mr 190,000 multidrug resistance protein (MRP) in drug-selected and transfected human tumor cells. Cancer Res. 55:102-110.

7. Jedlitschky, G., I. Leier, U. Buchholz, M. Center, and D. Keppler. 1994. ATP-dependent transport of glutathione $S$-conjugates by the multidrug resistance-associated protein. Cancer Res. 54:4833-4836.

8. Müller, M., C. Meijer, G.J.R. Zaman, P. Borst, R.J. Scheper, N.H. Mulder, E.G.E. de Vries, and P.L.M. Jansen. 1994. Overexpression of the gene encoding the multidrug resistance-associated protein results in increased ATPdependent glutathione $S$-conjugate transport. Proc. Natl. Acad. Sci. USA. 91: 13033-13037.

9. Ishikawa, T. 1992. The ATP-dependent glutathione $S$-conjugate export pump. Trends Biochem. Sci. 17:463-468.

10. Jansen, P.L.M., and R.P.J. Oude Elferink. 1993. Defective hepatic anion secretion in mutant $\mathrm{TR}^{-}$rats. In Hepatic Transport and Bile Secretion: Physiology and Pathophysiology, N. Tavoloni, and P.D. Berk, editors. Raven Press, New York. 721-731.

11. Leier, I., G. Jedlitschky, U. Buchholz, S.P.C. Cole, R.G. Deeley, and D. Keppler. 1994. The MRP gene encodes an ATP-dependent export pump for leukotriene $\mathrm{C}_{4}$ and structurally related conjugates. J. Biol. Chem. 269:2780727810.

12. Gekeler, V., W. Ise, K.H. Sanders, W.R. Ulrich, and J. Beck. 1995. The leukotriene LTD4 receptor antagonist MK571 specifically modulates MRP associated multidrug resistance. Biochem. Biophys. Res. Commun. 208:345-352.

13. Versantvoort, C.H.M., H.J. Broxterman, T. Bagrij, R.J. Scheper, and P.R. Twentyman. 1995. Regulation by glutathione of drug transport in multidrug resistant human lung tumour cell lines overexpressing $M R P$. Br. J. Cancer. 72:82-89.

14. Zaman, G.J.R., J. Lankelma, O. van Tellingen, J. Beijnen, H. Dekker, C. Paulusma, R.P.J. Oude Elferink, F. Baas, and P. Borst. 1995. Role of glutathione in the export of compounds by the multidrug resistance-associated protein. Proc. Natl. Acad. Sci. USA. 92:7690-7694.

15. Zaman, G.J.R., C.H.M. Versantvoort, J.J.M. Smit, E.W.H.M. Eijdems, M. de Haas, A.J. Smith, H.J. Broxterman, N.H. Mulder, E.G.E. de Vries, F Baas, and P. Borst. 1993. Analysis of the expression of MRP, the gene for a new putative transmembrane drug transporter, in human multidrug resistant lung cancer cell lines. Cancer Res. 53:1747-1750.

16. Burger, H., K. Nooter, G.J.R. Zaman, P. Sonneveld, K.E. van Wingerden, R.G. Oostrum, and G. Stoter. 1994. Expression of the multidrug resistance-associated protein (MRP) in acute and chronic leukemias. Leukemia. 8: 990-997.

17. Cordon-Cardo, C., J.P. O'Brien, D. Casals, L. Rittman-Grauer, J.L.
Biedler, M.R. Melamed, and J.R. Bertino. 1989. Multidrug-resistance gene (P-glycoprotein) is expressed by endothelial cells at blood-brain barrier sites. Biochem. J. 256:959-963.

18. Thiebaut, F., T. Tsuruo, H. Hamada, M.M. Gottesman, I. Pastan, and M.C. Willingham. 1987. Cellular localization of the multidrug resistance gene product in normal human tissues. Proc. Natl. Acad. Sci. USA. 84:7735-7738.

19. Schinkel, A.H., J.J.M. Smit, O. van Tellingen, J.H. Beijnen, E. Wagenaar, L. van Deemter, C.A.A.M. Mol, M.A. van der Valk, E.C. RobanusMaandag, H.P.J. te Riele, et al. 1994. Disruption of the mouse mdr1a P-glycoprotein gene leads to a deficiency in the blood-brain barrier and to increased sensitivity to drugs. Cell. 77:491-502.

20. Ueda, K., N. Okamura, M. Hirai, Y. Tanigawara, T. Saeki, N. Kioka, T. Komano, and R. Hori. 1992. Human P-glycoprotein transports cortisol, aldosterone, and dexamethasone, but not progesterone. J. Biol. Chem. 267:2424824252.

21. Schinkel, A.H., E. Wagenaar, L. van Deemter, C.A.A.M. Mol, and P. Borst. 1995. Absence of the mdr1a P-glycoprotein in mice affects tissue distribution and pharmacokinetics of dexamethasone, digoxin, and cyclosporin A. J. Clin. Invest. 96:1698-1705.

22. Graham, F.L., and A.J. van der Eb. 1973. A new technique for the assay of infectivity of human adenovirus 5 DNA. Virology. 52:456-467.

23. Schinkel, A.H., M.E.M. Roelofs, and P. Borst. 1991. Characterization of the human MDR3 P-glycoprotein and its recognition by P-glycoprotein-specific monoclonal antibodies. Cancer Res. 51:2628-2635.

24. Schinkel, A.H., S. Kemp, M. Dollé, G. Rudenko, and E. Wagenaar. 1993. $N$-glycosylation and deletion mutants of the human MDR1 P-glycoprotein. J. Biol. Chem. 268:7474-7481.

25. Oude Elferink, R.P.J., C.T.M. Bakker, and P.L.M. Jansen. 1993. Glutathione-conjugate transport by human colon adenocarcinoma cells (Caco-2 cells). Biochem. J. 290:759-764.

26. Di Virgilio, F., C. Fasolato, and H. Steinberg. 1988. Inhibitors of membrane transport system for organic anions block fura-2 excretion from PC12 and N2A cells. Biochem. J. 256:959-963.

27. Cunningham, R.F., Z.H. Israili, and P.G. Dayton. 1981. Clinical pharmacokinetics of probenecid. Clin. Pharmacokinet. 6:135-151.

28. Gilman, A.G., A.S. Rall, A.S. Nies, and P. Taylor. 1991. The Pharmacological Basis of Therapeutics. McGraw-Hill Book Co., Singapore. 1811 pp.

29. Gottardi, C.J., and M.J. Caplan. 1993. An ion-transporting ATPase encodes multiple apical localization signals. J. Cell Biol. 121:283-293.

30. Rodriguez-Boulan, E., and S. Powell. 1992. Polarity of epithelial and neuronal cells. Annu. Rev. Cell Biol. 8:395-427.

31. Matter, K., and I. Mellman. 1994. Mechanisms of cell polarity: sorting and transport in epithelial cells. Curr. Opin. Cell Biol. 6:545-554.

32. Saxena, M., and G.B. Henderson. 1995. ATP-dependent efflux of 2,4dinitrophenyl-S-glutathione. J. Biol. Chem. 270:5312-5319.

33. Oude Elferink, R.P.J., R. Ottenhof, W. Liefting, J. de Haan, and P.L.M. Jansen. 1989. Hepatobiliary transport of glutathione and glutathione conjugate in rats with hereditary hyperbilirubinemia. J. Clin. Invest. 84:476-483.

34. Sepulveda, F.V., and J.D. Pearson. 1985. Polarity of epithelial and neuronal cells. In Tissue Culture of Epithelial Cells. M. Taub, editor. Plenum Press, New York. 87-88.

35. Ullrich, K.J. (1994). Specificity of transporters for "organic anions" and "organic cations" in the kidney. Biochim. Biophys. Acta. 1197:45-62. 